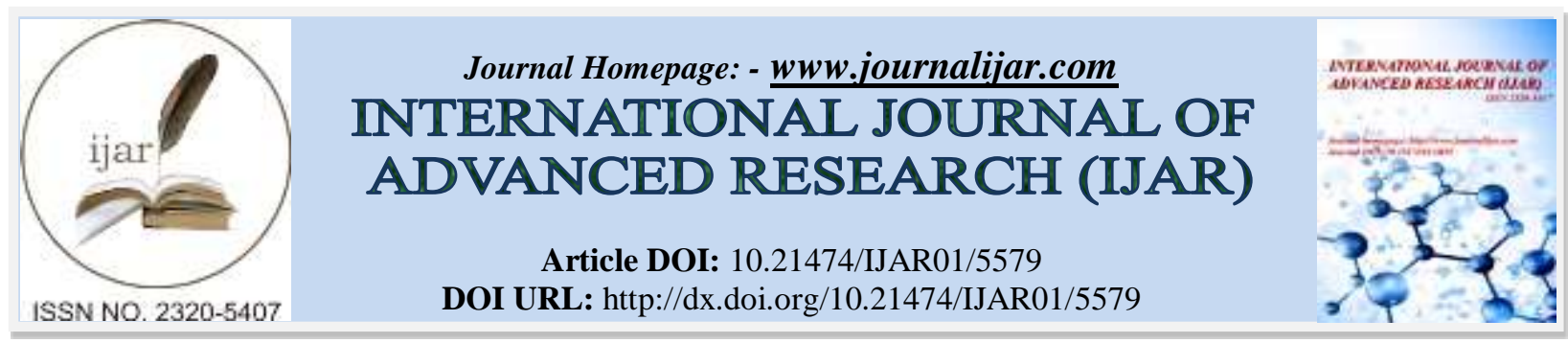

RESEARCH ARTICLE

\title{
EFFECT OF TEACHER INTERACTION STYLES ON GENDER DIFFERENCE IN CHEMISTRY IN SECONDARY SCHOOLS IN WARENG SUB-COUNTY, KENYA.
}

Tanui Chemeli Christine, Dr. Waswa Peter and Prof. John Simiyu. School of Education, University of Eldoret, P.O Box 1125, Eldoret Kenya.

\section{Manuscript Info}

Manuscript History

Received: 09 August 2017

Final Accepted: 11 September 2017

Published: October 2017

Key words:-

Interaction, Styles, Gender, chemistry, Achievement.

\begin{abstract}
Achievement test results over the years have shown an ever-increasing gap between the performances of boys and girls in chemistry in secondary schools. However, factors that are associated with this gender difference is unclear. The purpose of this study was to investigate the effect of teacher interaction styles on gender difference in chemistry and establish the Strategies of curbing gender difference in chemistry performance. This study adopted descriptive Survey Design and targeted 2,672 Form three and 73 chemistry teachers. The sample size for this study was determined using sample size determination formula by Yamane (1967). The data collection instruments were questionnaire, in-depth interview schedules and document analysis. Validity was determined through expert judgement while reliability was determined through piloting and use of Cronbach Alpha Coefficient. Qualitative data was analysed by use of frequencies, means standard deviation and percentages. Further Pearson Correlation were used to examine the relationships that exists between independent and dependent variables. The study findings showed that majority of male $(80.4 \%)$ and female $(87.7 \%)$ students in secondary schools believed that students who were taught by teachers who rely on lectures did not perform better in chemistry. Further, there was a significant relationship between teacher interaction styles and gender difference in chemistry in secondary schools $(\mathrm{r}=.358 ; \mathrm{p}=.002)$. The study recommended that there is need for teachers to encourage students to form discussion groups as this enhanced students' achievement in chemistry. In addition, the researcher findings would help secondary school students to identify the particular areas that give them problems in chemistry.
\end{abstract}

Copy Right, IJAR, 2017,. All rights reserved.

\section{Introduction:-}

Chemistry is an experimental science which relies primarily on the harmony between theory and practical. It should therefore be taught as such. It follows therefore, that, understanding of concept in practical chemistry will assist in enhancing student's understanding of chemistry (Ikeobi, 2010). In chemistry teaching, the importance of harmonizing practical work with theory cannot be over-emphasized. Omolade (2008) states that; if the academic achievement of students is to be enhanced, learners must have a deep understanding of the basic concepts behind practical task they engage in. This is because the observations and experiments, students carry out are meant to 
confirm some theories and the application of concepts. In spite of this important position of chemistry among other science and science related disciplines, students' academic achievement has consistently been below expectation and unimpressive (Jegede, 2010; Oloyede, 2010).

The influence of gender on students' academic achievement has for a long time been of concern to many researchers but no consistent result has been established. For instance, Okeke (2001) and Aluko (2005) reported that gender has no effect on student achievement in science.

Research in Australia indicates that gender differences in mathematics achievement are reducing and shifting (Forgasz, Leder \& Vale, 2000). Vale (2009) found that many studies conducted between 2000 and 2004 in Australasia showed no significant differences in achievement in mathematics between males and females, though males were more likely to obtain higher mean scores. Further, findings favouring females were evident more often in studies of primary students' achievement, particularly in New Zealand.

Samuel and John (2004) examined how the cooperative class experiment (CCE) teaching methods affect students' achievement in Chemistry. They found that there was no significant difference in gender achievement between the experimental and control groups, but girls had a slightly higher mean score than boys did. Moreover, the girls taught through CCE method performed better than girls taught through the conventional teaching method in the post-test scores. Similarly, boys who were taught using CCE method performed significantly better than the boys in the control groups in the post-test scores. The researchers also pointed out that there was no significant difference in achievement between boys and girls exposed to CCE method, both performed significantly better than those taught through conventional lecture method. This study was performed in Nigeria which has different characteristics as the Kenyan high schools and therefore the researcher investigated the effect of teacher interaction styles on gender difference in chemistry achievement in secondary schools in Wareng Sub-County of Kenya.

\section{Statement of the Problem:-}

Achievement test results over the years have shown an ever-increasing gap between the performances of boys and girls in chemistry at senior secondary school level (Onekutu, 2002). While most people in the society recognize and appreciate the essential role of chemistry in everyday life, it remains one of the poorly performed subjects in the K.C.S.E national examinations (KNEC, 2010). For many years now, there seems to be a trend in the performance of girls and boys in Senior Secondary School Chemistry where girls have not been performing as well as boys. Most of the time, girls tend to simply avoid doing science related subjects. In addition, gender disparity in performance does exist. However, factors that are associated with this gender difference is unclear and therefore this study investigated the gender difference in achievement in chemistry in secondary schools in Wareng Sub-County.

\section{Purpose of the Study:-}

The purpose of this study was to examine the effect of teacher interaction styles on gender difference in chemistry in secondary schools in Wareng Sub-County.

\section{Hypothesis of the study:-}

HO$_{1}$ : There is no significant relationship between teacher interaction styles and gender difference in chemistry in secondary schools in Wareng Sub-County

\section{Literature Review:-}

Much research has focused on gender differences in various areas of intellectual achievement (Halpern, 2012). In fact, reliance on this research often guides policy decisions such as funding for sex-segregated education (Lindberg, Hyde, Petersen, \& Linn, 2010). In reality, much of what we know about gender differences in intellectual achievement comes from various meta-analyses that have summarized and quantified the findings obtained in relevant research.

Generally, teachers usually interact differently with boys and girls and some evidence suggests that students benefit academically from having teachers who are of the same gender as themselves (Dee, 2007). Cantrell, Liu, Leverington and Taylor (2007) reported no gender differences in science achievement when three levels of interactive technology were integrated in learning. 
The student's achievement and examination of effective factors in student learning are themes on which many educational researches are based. There are so many factors contributing to students' achievement, one of which is teacher/student's interaction in the classroom. The importance of interaction between teachers-students in supporting positive learner outcomes is well documented (Tello, 2000; Mahmoodi, Fathiazar, \& Esfandyari, 2010; Clarke, Keitel, \& Shimizu, 2011). Bloom as cited in Mahmoodi (2016) pointed out that we must begin to examine what teachers do, not what teachers are. Many educational researchers believe that we need to examine the teaching and learning process through observational techniques and to emphasize process-product research rather than inputoutput research.

The instructional interaction between teacher and students is a critical aspect of this paper. Brophy (2000) says that engagement rates depend on the teacher's ability to organize the classroom as an efficient technique. Pascarella and Chapman (1983) as cited in Mahmoodi (2016) found that the amount and content of formal and informal studentsteacher interaction enhance student achievement (Pascarella \& Chapman, 1983). Flanders (1970) as cited in Mahmoodi (2016) conducted extensive studies regarding student-teacher interaction in the face-to-face classroom and concluded that increased interaction between student-teacher was positively correlated with student achievement and attitudes toward learning. Jackson (1990) discovered that the teachers engaged in, as many as 1000 exchanges with students every day. Some students received as few as five contacts a day, and other students as many as 120 contacts.

There is overwhelming evidence of a common pattern of interaction in classrooms best summarized in Flanders "rule" of two-third'; that is, in almost all classrooms, two-thirds of the time someone is talking and two-third of that time it is the teacher who speaks (Walker, 2002). Teachers speak in the classroom on the average $70 \%$ of the time. Almost all teachers give "lectures" lasting around $30 \mathrm{~min}$, ask few, mostly ritualistic, "questions" and rarely address their audience directly (Fathi, 2011).

The indirect interactions are more participatory and more typical of the types of interactions that promote the construction of concepts (Hagevik, 2003). Students of indirect teachers made better achievement scores, produced higher levels of critical thinking, and gave more active manifestations of curiosity than did students of direct teachers (Walker, 2002). Many studies show that male students consistently achieve higher than their female counterparts in science (Okonkwo \& Eke, 2005, Njoku, 2007, Okigbo \& Akusoba, 2009). However, this study examined the effect of teacher interaction styles on gender difference in chemistry in secondary schools in Wareng Sub-County, Kenya and found out that there was a significant relationship between teacher interaction styles and gender difference in chemistry in secondary schools. This shows that teacher interaction styles applied in classrooms influences students' achievement in chemistry based on gender.

\section{Methodology:- \\ Research Design:-}

Creswell (2009) defines research designs as plans and the procedures for research that span the decisions from broad assumptions to detailed methods of data collection and analysis. This study will adopt descriptive Survey Design. Descriptive survey design enables the researcher to describe the state of affairs as they are and report the findings (Kombo \& Tromp, 2009). In addition, descriptive research designs are usually structured and specifically designed to measure the characteristics described. Hypotheses derived from the theory usually serve to guide the process and provide a list of what needs to be measured (Hair, Babin, money \& Samouel, 2003). In this study, the researcher was interested in describing the factors that influenced gender difference in chemistry among secondary school students in Wareng Sub-County.

\section{Target Population:-}

Wareng Sub-County has 62 public secondary schools with a student population of 10664 students and 73 chemistry teachers (DEO, Wareng Sub-County, 2015). However, in this study form three students were targeted due to the fact that subject specialization begins in form three. There were 2672 form three students who formed the target population. In addition, the 73 chemistry teachers were targeted.

\section{Sample Size and Sampling Procedures:-}

Sampling is the process of selecting a sub-set of cases in order to draw conclusions about the entire set. A sample is a small part of large population, which is thought to be representative of the larger population (Orodho, 2003). The 
sample size for this study was determined using sample size determination formula by Yamane (1967). The formula is given as:

$$
\mathrm{n}=\frac{N}{1+N(e)^{2}}
$$

Where

n- The sample size

$\mathrm{N}$ - The population size

e - The acceptable sampling error

For students:

$$
\mathrm{n}=\frac{2672}{11+2672\left(.05^{2}\right)}=348
$$

The 348 students were selected by use of simple random sampling technique.

\section{Research Instruments:-}

The data collection instruments for this study included questionnaire, interview schedules and document analysis. A questionnaire refers to a collection of items to which a respondent is expected to react usually in written (Kothari, 2008). Closed ended questionnaires were administered to chemistry students in the selected secondary schools.

Interview schedule was administered to chemistry teachers. This method was employed because it allows for indepth analysis of issues which is not possible to get from questionnaires. It also makes use of prompts and probes to get a deeper insight of the gender difference in achievement in chemistry. In this study, students' achievement in chemistry was obtained from records that existed within the schools visited.

\section{Validity and Reliability of the Research Instruments:-}

Validity refers to the accuracy, correctness, meaningfulness of inferences and soundness of results of conclusion, which are based on the research findings (Kothari, 2008; Mugenda, 2003). Foxcroft et al., (2004), note that by using a panel of experts to review the test specifications and the selection of items, the content validity of a test can be improved. To test the validity of the instruments used in the study, the questionnaire was availed to supervisors together with a panel of experienced researchers of University of Eldoret to review the instruments. The results from the piloting together with the comments from the experts were incorporated in the final instrument revisions to improve on validity.

Reliability refers to the consistency that an instrument demonstrates when applied repeatedly under similar conditions (Borg \& Gall, 1993). To determine the reliability of the instrument, student questionnaire was piloted in secondary schools in Eldoret West Sub-County. Cronbach Alpha Coefficient was used to test on the reliability of the instruments. A reliability coefficient of over 0.7 indicated that the instruments are reliable (Orodho, 2009). In this study, a reliability coefficient of 0.74 was obtained showing that the instruments were reliable and therefore were adopted for data collection.

\section{Data Analysis:-}

Raw data was appropriately coded and tabulated in readiness for analysis. The SPSS computer package version 20 was used as a 'toolbox' to analyse data related to objectives. Quantitative data was analysed by use of mean standard deviation and the ranges, percentages, pie charts, bar graphs, and frequencies of occurrences. Qualitative data was analysed thematically as per the research objectives of the study. Further Pearson Correlation were used to examine the relationships that exist between independent and dependent variables.

\section{Ethical Considerations:-}

The researcher sought permission and authority to conduct the study from University of Eldoret, and National Commission for Science Technology and Innovations (NACOSTI). Secondly the participants were assured that the information given would be used for the purpose intended only (Kombo \& Tromp, 2006). Thirdly, the researcher assured the respondents of confidentiality and anonymity of any information they provided. In addition, all information was cited to avoid cases of plagiarism. 


\section{Results and Discussions:-}

The aim of this study was to examine the effect of teacher interaction styles on gender difference in chemistry achievement in secondary schools in Wareng Sub-County. To achieve this objective, the respondents were asked to rate their level of agreement on a five point Likert scale items in the questionnaire on effect of teacher interaction styles on gender difference in chemistry. The results of data analysis are presented in Table 1.

Table 1:- Students' Responses on Effect of Teacher Interaction Styles on Gender Difference in Chemistry Achievement.

\begin{tabular}{|l|l|l|l|l|l|l|l|l|l|l|l|}
\hline Statement & Gender & SD & & D & & UD & & A & & SA & \\
\cline { 2 - 11 } & & F & $\%$ & F & $\%$ & F & $\%$ & F & $\%$ & F & $\%$ \\
\hline $\begin{array}{l}\text { Students who are taught } \\
\text { by teachers who rely on } \\
\text { lectures perform better in } \\
\text { chemistry. }\end{array}$ & Male & 77 & 49.4 & 49 & 31.4 & 17 & 10.9 & 10 & 6.4 & 3 & 1.9 \\
\hline & Female & 87 & 50.9 & 63 & 36.8 & 13 & 7.6 & 1 & 0.6 & 7 & 4.1 \\
\hline $\begin{array}{l}\text { Girls join chemistry } \\
\text { discussion groups } \\
\text { perform well in } \\
\text { chemistry as compared to } \\
\text { their male counterparts. }\end{array}$ & Male & 53 & 34.0 & 29 & 18.6 & 18 & 11.5 & 16 & 10.3 & 40 & 25.6 \\
\hline & Female & 96 & 56.1 & 26 & $15 . .2$ & 5 & 2.9 & 35 & 20.5 & 9 & 5.3 \\
\hline $\begin{array}{l}\text { Direct teacher student } \\
\text { interaction favours boys } \\
\text { in chemistry. }\end{array}$ & Male & 11 & 7.1 & 16 & 10.3 & 18 & 11.5 & 34 & 21.8 & 77 & 49.4 \\
\hline & Female & 7 & 4.1 & 3 & 1.8 & 21 & 12.3 & 88 & 51.5 & 52 & 30.4 \\
\hline $\begin{array}{l}\text { Girls who are given } \\
\text { questions and guided by } \\
\text { teachers perform better } \\
\text { than their male } \\
\text { counterparts. }\end{array}$ & Male & 12 & 7.7 & 7 & 4.5 & 35 & 22.4 & 30 & 19.2 & 72 & 46.2 \\
\hline & Female & 0 & 0.0 & 0 & 0.0 & 16 & 9.4 & 50 & 29.2 & 105 & 61.4 \\
\hline $\begin{array}{l}\text { Students who are } \\
\text { explorative perform } \\
\text { better in chemistry. }\end{array}$ & Male & 17 & 10.9 & 31 & 19.9 & 20 & 12.8 & 46 & 29.5 & 42 & 26.9 \\
\hline
\end{tabular}

Table 1, shows that $77(49.4 \%)$ male and $87(50.9 \%)$ female students strongly disagreed with the statement that students who are taught by teachers who rely on lectures perform better in chemistry, 49(31.4\%) male and 63(36.8\%) female students disagreed with the statement, 17(10.9\%) male and 13(7.6\%) female students were undecided on the statement and 10(6.4\%) male and $1(0.6 \%)$ female students agreed with the statement while $3(1.9 \%)$ male and $7(4.1 \%)$ female students strongly agreed with the statement. The study findings showed that a majority of male $(80.4 \%)$ and female $(87.7 \%)$ students in secondary schools in Wareng Sub-County believed that students who were taught by teachers who rely on lectures did not perform better in chemistry. However, there were more female students than male students were of the view that that use of lecture method was disadvantageous in chemistry. This was found to be supported by an earlier work of Ifeakor, Njelita and Udogu (2008) who found out in their study that the traditional methods such lecture method did not tend to foster critical and creative thinking, and collaborative problem-solving. It may need to be pointed that no one method of teaching chemistry is ideal all the time.

In addition, 53(34.0\%) male and 96(56.1\%) female students strongly disagreed with the statement that girls who were praised by their chemistry teachers performed well in chemistry as compared to their male counterparts, $40(25.6 \%)$ male and 9(5.3\%) female students strongly agreed with the statement, 29(18.6\%) male and 26(15.2\%) female students disagreed with the statement, 16(10.3\%) male and 35(20.5\%) female students agreed with the statement while $18(11.5 \%)$ male and 5(2.9\%) female students were undecided on the statement. The study findings showed that majority of both male (52.6\%) and female (71.3\%) students were of the view that girls who were praised by their chemistry teachers did not perform well in chemistry as compared to their male counterparts. 
However, a larger percentage of female students were in disagreement with the statement as compared to male students. This implies that despite praising girls, they still performed low in chemistry as compared to their male counterparts.

On the statement that boys who are acknowledged by their teachers perform better in chemistry, $77(49.4 \%)$ male and 52(30.4\%) female students strongly agreed with the statement, 34(21.8\%) male and 88(51.5\%) female students agreed with the statement, 18(10.3\%) male and 21(12.3\%) female students were undecided on the statement and $11(7.1 \%)$ male and $7(4.1 \%)$ female students strongly disagreed with the statement while $16(10.3 \%)$ male and $3(1.8 \%)$ female students disagreed with the statement. From the responses, it can be shown that a majority of both male $(71.2 \%)$ and female $(81.9 \%)$ students reported that boys who were acknowledged by their teachers performed better in chemistry. This implied that praising boys enhances that performance in chemistry as compared to their female counterparts. According to Brophy (2014) teacher praise has for different motives like better performance and has a positive effect on students' performance.

Similarly, 72(46.2\%) male and 105(61.4\%) female students strongly agreed with the statement that girls who were given questions and guided by teachers performed better than their male counterparts, 30(19.2\%) male and $50(29.2 \%)$ female students agreed with the statement and 35(22.4\%) male and 16(9.4\%) female students were undecided on the statement while 19(12.2\%) male students were in disagreement with the statement. From the responses, it can be shown that a majority of both male $(65.4 \%)$ and female $(90.6 \%)$ students in secondary schools in Wareng Sub-County believed that giving questions to girls and guiding them on how to answer enhanced their achievement in chemistry as compared to their male counterparts. This implies that despite praising girls, they still performed low in chemistry as compared to their male counterparts. Palmer, (2007) noted that positive verbal statements of encouragement and praise can strongly influence student motivation. Praise for effort and for improvement can build a student's self-confidence. Esteem can be boosted by emphasizing his or her performance relative to personal goals.

In addition, 42(26.9\%) male and 90(52.6\%) female students strongly agreed with the statement that students who are explorative perform better in chemistry, 46(29.5\%) male and 49(28.7\%) female students agreed with the statement, $31(19.9 \%)$ male and $6(3.5 \%)$ female students disagreed with the statement and $20(12.8 \%)$ male and $18(10.5 \%)$ female students were undecided on the statement while $17(10.9 \%)$ male and $8(4.7 \%)$ female students strongly disagreed with the statement. From the responses, it emerged that a majority of both male (56.4\%) and female $(81.3 \%)$ students were of the view that students were explorative in nature performed better in chemistry subject. For both boys and girls, discovery-oriented approach is effective when considering high level of cognitive skills. . For both boys and girls, discovery-oriented approach is effective when considering high level of cognitive skills (Busolo, 2010). For those teachers who use more of the conventional instructional approaches, a blend with experiential components may increase the level of performance. Further, in chemistry education it is very important that individuals reach knowledge by exploring on their own, and revise their world point of views as they reach new knowledge and develop an eagerness to learn (Sezgin Saf, 2011).

\section{HYPOTHESIS TESTING}

The hypothesis of this study stated that;

$\mathbf{H O}_{1}$ : There is no significant relationship between teacher interaction styles and gender difference in chemistry achievement in secondary schools in Wareng Sub-County. Pearson correlation analysis was used to test this hypothesis and the results are presented in Table 2.

Table 2:- Relationship between Teachers' Interaction styles and Gender Difference in Chemistry Achievement

\begin{tabular}{|l|l|c|}
\hline \multicolumn{2}{|c|}{ Gender } & Interaction Styles \\
\cline { 2 - 3 } & Pearson Correlation & $.358^{*}$ \\
\cline { 2 - 3 } & Sig. (2-tailed) & .002 \\
\cline { 2 - 3 } & $\mathrm{N}$ & 327 \\
\hline
\end{tabular}

*. Correlation is significant at the 0.05 level (2-tailed).

Table 2 shows that there was a significant relationship between teacher interaction styles and gender difference in chemistry achievement in secondary schools $(\mathrm{r}=.358 ; \mathrm{p}=.002)$. This shows that teacher interaction styles applied in classrooms influences students' achievement in chemistry based on gender. 


\section{Conclusions and Recommendations:-}

There was a significant relationship between teacher interaction styles and gender difference in chemistry achievement in secondary schools. This shows that teacher interaction styles applied in classrooms influences students' achievement in chemistry based on gender. Student centered teaching approaches enhances their performance in chemistry therefore chemistry teachers need to embrace student centered teaching approaches.

\section{References:-}

1. Brophy J. (2000). Teacher influences on student achievement. In: Smith PK, Pellegrini AD, editors. Psychology of Education: Major Themes. Vol. 1. New York: Routledge Falmer.

2. Brophy, J. (2014). Teacher Praise: A Functional Analysis. Review of Educational Research, 51(1) 23-32.

3. Busolo, J (2010). Gender differences in students' achievement in chemistry in secondary schools of Kakamega District, Kenya. Unpublished MED thesis, Kenyatta University.

4. Cantrell, P., Liu, L., Leverington, M. \& Taylor, J. (2007). The effects of differentiated technology integration on student achievement in middle school science classrooms. International Journal of Technology in Teaching and Learning, 3(3), 36-54.

5. Clarke, D., Keitel, H. \& Shimizu, Y (2011). Mathematics Classrooms in Twelve Countries: The Insider's Perspective. Rotterdam: Sense Press.

6. Cohen, L., Manion, L \& Morrison, K (2007). Research Methods in Education: $6^{\text {th }}$ edition. Routledge, New York, USA.

7. Creswell, J (2009). Research Design: Qualitative, Quantitative, and Mixed Methods Approaches. $3^{\text {rd }}$ Ed Sage Publishers, London, UK.

8. David, K.D. \& Stanley, H.L. (2000). Effect of Gender on Computer-based Chemistry Problem-solving. Electronic Journal of Science Education, 4 (4).

9. Dawson, C. (2000). Upper primary boys and girls interest in science: have they changed since 1980. International journal of science education, 22(6), 557-570.

10. Dee T. S. (2007). Teachers and the gender gaps in student achievement. Journal of Human Resources, 42(3) 528-554.

11. Fathi A (2011). The Relationship between Self-Efficacy and Quality of Teaching in Tabriz' High Schools Based on Flanders Interaction Analysis. Unpublished Master's Thesis, University of Tabriz, Tabriz, Iran.

12. Fisher, D. \& Rickards T. (1998). Associations between teacher-student interpersonal behavior and student attitude to mathematics. Math Educ Res $J$ 1; 10:3-15.

13. Forgasz, H. J., Leder, G. C. \& Vale, C. (2000). Gender and mathematics: Changing perspectives. In K. Owens and J. A. Mousley (Eds). Research in mathematics education in Australasia 1996-1999. (pp.305-340). Turramurra, NSW: Mathematics Education Research Group of Australasia Inc.

14. Foxcroft, C., Paterson, H., le Roux, N \& Herbst, D. (2004). Psychological assessment in South Africa: A Needs Analysis. The test patterns and needs of psychological assessment practitioners. Final Report.

15. Hagevik R.A (2003). The impact of electronic networking on student interactions during an ant biomonitoring problem solving science investigation. Meridian; 6:8-17.

16. Halpern, D. F. (2012). Sex differences in cognitive abilities ( $4^{\text {th }}$ ed.). New York, NY: Psychology Press.

17. Ifeakor, A.C., Njelita, C.B \& Udogu, M.E (2008). An appraisal of senior secondary school teachers' awareness and usage of innovative instructional strategies and evaluation techniques in teaching chemistry. Proceedings of the $49^{\text {th }}$ Annual Conference of STAN, 116-121.

18. Ikeobi, I. O. (2010). Beyond the Stereotype Thoughts and Reflections on Education. The CIBN Press Limited, Ibadan, Nigeria.

19. Jackson, P.W (1990). Life in Classroom. New York: Teacher Collage Press.

20. Jegede, S. A. (2010). Nigerian Students Perception of Technical Words in Senior Secondary School Chemistry Curriculum. Pakistan Journal of Social Sciences 7(2), 109-111.

21. Kothari, C. R. (2008). Research Methodology, Methods and Techniques (2nd ed., pp. 109-110). New Delhi: New Age Inter- national (P) Limited.

22. Latif, E., \& Miles, S., (2011). The impact of assignments on academic performance. Journal of Economic and Economic Education Research, (Nov. 2011), 12 (3).

23. Lindberg, S. M., Hyde, J. S., Petersen, J. L., \& Linn, M. C. (2010). New trends in gender and mathematics performance: A meta-analysis. Psychological Bulletin, 136, 1123-1135.

24. Mahmoodi F. (2016). The effect of teacher talk style on student achievement. Int J Educ Psychol Res [serial online]. Available from: http://www. ijeprjournal. org/text. Asp. 
25. Mahmoodi, F., Fathiazar, S \& Esfandyari, R (2010). The investigation of the relationship between active participation of students and their academic achievement in the process of teaching. Found Educ 10:65-82.

26. Njoku, B.A. (2007) Performance trend of students in chemistry in the senior secondary schools' certificate

27. examinations. Alvana Journal of science, 3, (2), pp 160- 172.

28. Okeke, E. A. C. (2001). Women in Science Technology and Mathematics in Nigeria: Key note address. In O. O. Busari (ed). Women in Science Technology in Nigeria. 42 ${ }^{\text {nd }}$ Annual Conference Proceedings of the Science Teachers Association of Nigeria 3-13.

29. Okigbo, E.C. \& Akusoba, (2009) A comparison of the use of card games and expository method of teaching and learning algebraic expression. UNIZIK Journal of STM Education.1. pp 14-18.

30. Okonkwo, G.I.N. \& Eke, P.U. (2005) Students cognitive styles in integrated science. The educational Psychologist, 1,2 pp.133-140.

31. Okwo, F. A. \& Otunba, S (2007). Influence of Gender and Cognitive Styles in Science Achievement in Physics Essay Test. Journal of Science Teachers Association of Nigeria 42 (1\&2), 85-88.

32. Owiye, J.S \& Yara, P.O (2011). School Location and Academic Achievement of Secondary School in Ekiti State, Nigeria. Asian Journal of Social Science, 7 (5), 170-175.

33. Palmer, D. (2007). What Is the Best Way to Motivate Students in Science? Teaching Science-The Journal of the Australian Science Teachers Association, 53(1), 38-42.

34. Tello, S. F. (2000). An Analysis on the Relationship between Instructional Interaction and Student Persistence in Online Education. Available from: http://www.alnresearch. Org/data/dissertationtext/tello-Dissertation.pdf.

35. Vale, C. (2009). Trends and factors concerning gender and mathematics in Australasia. Retrieved on 21, November, 2014 from http://tsg.icmell.org/ document/ get/169.

36. Walker, G. H., (2003). Lecturing with style. The University of Tennessee. Chattanooga. 